\author{
R.B. Mazhenova ${ }^{1}$, G.B. Beisenbekova ${ }^{1}$, M.K. Yelshina ${ }^{1} *$ J. Danek ${ }^{2}$ \\ ${ }^{I}$ Karagandy University of the name of academician E.A. Buketov, Kazakhstan \\ ${ }^{2}$ Saint Cyril and Methodius University, Trnava, Slovakia \\ (*Corresponding author's e-mail: m.yelshina@mail.ru)
}

\title{
Formation of the polylingual personality of pupils of secondary school
}

\begin{abstract}
The article is devoted to the consideration of the relevance of multilingual education in the Republic of Kazakhstan and the formation of a multilingual personality of students in secondary schools. The definition of the concepts of polylingualism and polylingual education is available in this article. The authors analyzed various approaches and definitions of the concepts of «linguistic personality», "polylingual personality» and «polylingual personality of pupil». Language education of a pupil as a linguometodic category is a process and result of cognitive activity aimed at mastering the basics of language theory for communication purposes, at speech, mental and aesthetic development, and at mastering the culture of a native speaker of a given language. The article presents the main aspects of language learning in the modern world. The authors considered the levels of formation of a polylingual personality according to the linguist G.I. Bogin. The authors analyzed and systematized the main requirements for the formation of a multilingual student's personality. In addition, the degree of proficiency in several languages of secondary school students is determined. To achieve the effectiveness of the pedagogical process aimed at the formation of a polylingual personality of the student, the necessity of using active teaching methods, developing special techniques and creating pedagogical conditions was shown.
\end{abstract}

Keywords: linguistic personality, polylingual personality, polylingual personality of pupil, polylingual education, polylingual individual, polylingualism, multilingualism.

Our era is an era of positive changes. Today we are witnessing an increased focus on personal development in the process of establishing a new education system. This process is accompanied by significant changes in the pedagogical theory and practice of the educational process. New content, new approaches, new law, and other relationships are proposed. At the present stage of life, when automated machines replace human resources, there is an urgent need to form individuals who speak several languages at the same time.

Language policy of our Republic are legally defined in several documents, namely the Constitution, the «Law on languages in RK», the State program of education development of Kazakhstan for 2020-2025, the concept of language policy of Kazakhstan, the cultural project «Trinity of languages», «Intellectual nation 2020» and others. The core idea of these documents can be defined as follows: every citizen of the Republic of Kazakhstan must acquire several languages.

The first President of the Republic of Kazakhstan N.A. Nazarbayev has repeatedly noted that the educational reform should reach a level at which any citizen of our country, having received the appropriate education and qualifications, can become a sought-after specialist in any country of the world. In his The Message to the people of Kazakhstan, N.A. Nazarbayev noted that «the main criterion for the success of the educational reform is to reach such a level that any citizen of the country who has received the appropriate knowledge and skills will become a sought-after specialist in any country of the world. We must achieve quality educational services throughout the country at the level of world standards». The formation of a competent and conscious person who is able to conduct socio-cultural relations between multilingual States, get acquainted with the culture, literature, and history of various countries, using the need, without getting used to other cultures, to express their country and culture [1].

The modern education system focuses on the formation of a multicultural, polylingual personality. For Kazakhstan, with its special history and geopolitical position, one of the main tasks in the education system and the further development of society and the country as a whole is to educate a competitive specialist who can choose his place in life, quickly adapt to any environment, show knowledge and skills in a particular field of science, express his thoughts and opinions.

According to the founder of pedagogical science Ya.A.Komensky, polylinguism or «polyglot», has a long history. According to his linguo-didactic concept, «a literate person should know several languages: the native language for «private life», neighboring peoples' language (languages) for communication, Latin for reading scientific books, Greek and Arabic for philosophers and doctors, Greek and Jewish for theologists. 
At the same time, a great importance was given to the native language and Latin, which should be learned thoroughly [2].

The UNESCO confirmed the term «polylingual education» that means the use of not less than three languages, i.e, native, regional and international language in education which was adopted by General Conference in the 12th resolution, 1999 [3].

M.M. Fomin writes that «the ability to master several languages is a special kind of individual ability. Learning two, three or more languages is a means of accessing a multicultural space. Polylinguism is a term essentially adequate to multiculturalism» [4].

Polylingualism is a progressive phenomenon in the context of globalization, as it promotes mutual understanding and cooperation of peoples, the development of native languages, and the improvement of the General culture of a person. It is based on the formation of linguistic competence of students, including linguistic competence (theoretical knowledge about language); language competence (practical language); communicative competence (use of language in accordance with the situations of communication); cultural (the entry into the culture of the target language, overcome cultural barriers in communication).

Polylingual education is a purposeful process of forming a polylingual personality on the basis of simultaneous mastering of three and even more languages.

As one of the main tasks of education in the XXI century during the higher scientific and technical achievements, Professor G.G. Nauryzbay put forward the following problems:

1. education of a multicultural personality;

2. formation of a polylingual individual [5].

First of all, let's briefly analyze the concepts of «individual» and «personality». An individual is the relation of a person to a certain genus, the embodiment of natural, original qualities of this genus. Personality is a complex psychological structure, a set of social qualities that make up a system of relationships, a socially stable, acquired motivational need for a natural attitude. If we generalize and analyze the definition of personality, it is the totality of all the properties of the individual, performed depending on the environment. Personal development is carried out in the conditions of activity (including language communication), socialization of the individual and purposeful education. The personality develops and is formed. It creates a social system, namely, a social «system» of the individual, that is, it allows you to work in the social life of a person not only in a collective, but also in an individual form [6].

Yu.N. Karaulov defines «linguistic personality» as a set of abilities and characteristics that connect human speech, composition and reproduction of texts, which differ in the degree of structural and linguistic complexity, depth and accuracy of representation of reality, a certain purposefulness. He considers the linguistic individual as a form of linguistic learning in a comprehensive approach.

The concept of linguistic personality is connected with the personal consciousness and attitude of the linguistic person. Every person expresses himself not only through subject activity, but also through communication without language and meaninglessness. A person's words inevitably reflect his inner world, serve as his source of knowledge and personality. At the same time, it is obvious that it is impossible to teach a person outside the language, because it is difficult for us to understand what a person is like until we hear how and what he says. It is also impossible to «separate the language from the person», because without a person who speaks the language, it will not exceed the system of signs. According to Yu.N. Karaulov «a linguistic personality is an irreplaceable idea», which «goes through all aspects of language learning and at the same time breaks the boundaries between disciplines taught by a person outside his own language». Linguistic personality is a full-fledged form of personality, which includes mental, social, ethical and other components, but its language is interpreted in its own way through its discourse. The formation of personality is carried out through educational activities, which involve not only external attributes of integration, but also cooperation with its internal content, self-development of subjects of the educational process, the manifestation of their personal activity [7].

The concept of «polylingual personality» implies, on the one hand, as a versatile person who is ready to conduct a cultural dialogue both in their native and foreign languages, both in their native and in the languages of other peoples, taking into account and knowing the peculiarities of behavior and speech of representatives of other cultures. On the other hand, this concept reflects on a broader scale modern linguistic educational processes for the introduction of multilingualism, which contributes to the assimilation of students of other language knowledge, cultural values and traditions of peoples, lifestyle, and respect for the values of other countries. Thus, a polylingual person is a cultural and historical person who has not only an identity, but also its own social specificity and ethnic basis. 
In real life, polylingualism (multilingualism) is a fairly rare phenomenon. Especially as a mass phenomenon, it does not occur. The main aspects of language research in the modern era are summarized as follows:

1. Learn your native language. In all countries of the world, native languages are studied in schools for the practical purpose of better mastering the vocabulary, grammatical structure and phonetic system of this language.

2. Learning a non-native language for the purpose of practical mastering it, that is, a second language, which leads to the development of bilingualism of various degrees (learning the language of international communication in a multinational state, learning foreign languages in schools, universities, using bilingualism for scientific purposes, in international relations, and so on).

3. Research of languages for scientific purposes (development of a general theory of language, comparative-historical study of languages, etc.).

The main goal of the second aspect of language learning is the development of polylanguage, training people who know several other languages besides their native language.

Language education of a pupil as a linguometodic category is a process and result of cognitive activity aimed at mastering the basics of language theory for communication purposes, at speech, mental and aesthetic development, and at mastering the culture of a native speaker of a given language. At the same time, when describing language education as a process, the learning goals, content, teaching methods, organizational forms, and methodological conditions are traditionally taken into account.

Yu.N. Karaulov convinces that intelligence is observed in a language more powerful and is studied through language. But the intellectual qualities of a person do not appear at any level of language proficiency and language use. So Yu.N. Karaulov identifies several levels of mastering the familiar language:

level $0-$ a set of structural characteristics of the semantic-nationwide language type. This invariant part provides both the possibility of mutual understanding of the suppliers of various dialects, and the ability to understand texts lagging behind the existence and functioning of their linguistic personality to a considerable depth;

the first level is linguistic-cognitive (reflected in the description of the linguistic model of the personality world). A linguistic personality begins on the sides of a familiar language, when intellectual forces participate in the game, and the first level of his education is the definition, fixing the value of the hierarchy of values in his picture of the world, its thesaurus. This level involves the separation and analysis of its variable, the variational part in the picture of the world, a peculiar and unique part for a given person;

the second level is a higher motivational type of analysis of the linguistic personality with respect to the linguo-cognitive level includes the definition and description of expressions and goals affecting its development, sequence, controlling the production of the text and ultimately determining the hierarchy of its meanings and values in the language model of the world. At this level, the study of a linguistic personality as an object is associated with a person in the most general, global socio-psychological sense, since, by definition, a linguistic personality is a person expressed in a language (texts) and a language reconstructed in its basic characteristics on the basis of linguistic means [8].

Thus, the formation of a polylingual personality of pupil can be achieved in three ways, as defined by Yu.N. Karaulov:

1) from the psychology of language and speech - the psycholinguistic path.

2) from the laws of language learning - the linguodidactic way.

3) starting with the study of the language of fiction, and most importantly, based on speech. However, among the ways of forming an artistic image, a significant role is played by the moment of listening, the moment when the character perceives the speech of other characters.

In this question, we refer to the definition of the linguist G.I. Bogin, who deals with the problems of a polylingual personality: «a person has the generic ability to be a polylingual person, but each individual must still be» $[9,2]$. G.I. Bogin belongs to the typology of the levels of education of a polylingual personality. As a criterion for the development of a polylingual personality, the researcher considered the degree of development of discursive thinking in a person.

In his works, G.I. Bogin divides the formation of a polylingual personality into five levels, each of which corresponds to different degrees of readiness of the speaker to perform speech actions. The Bogin model is not only related to the ontogenetic characteristics of human speech development; it shows a different degree of proficiency in a common language and says that it is independent of the age of the person. 
The first level, which the researcher called the degree of fidelity. This is the initial stage of language proficiency, access to which depends on who owns «this particular language with its simple rules». [9, 7]. Usually, the norm for this level of children reach 6-7 years, then the child's thought is at the pre-operative stage.

The second level is the speed level or interiorization. At this stage of development, the language personality rises depending on the adolescent age (from 10 to 11 years), which corresponds to the period of specific operations for the formation of the game. The main characteristic of this level is the development of the mechanism of internal speech, which allows you to increase the speed of creating discourses.

The third level or saturation level. A person usually reaches the age of 15-16 years. In the development of the game, it corresponds to the stage of formal operations. It is at the stage of formation of a polylingual personality that its desire for differentiated use of language means of various internal languages is observed.

Further development of a polylingual personality, according to G.I. Bogin, does not depend on age. It is largely due to the formation of a culture of communication in the broadest sense of the term. Thus, the fourth level is the level of adequate choice, after which a person becomes the «owner of the visual aids» and learns to use the stylistic resources of the language adequately.

The last, higher level is the fifth level of adequate synthesis, the mastery of which allows a person to achieve speech effects similar to the effects of fiction.

«The set of controls», the researcher confirms, «shows that a polylingual learner moves to the interiorization of speech by mastering the high-frequency tools of direct nomination, which gives him lexical and grammatical knowledge and further freedom in choosing the means of expression from a set of potential subjects». Achieving this freedom allows a developed person to operate with the whole text in such a way as to optimally reflect on the content of the text form, to participate as a «meaningful form» $[9,9-10]$.

G.I. Bogin's linguodidactical model is the first step in the study of the development of a pupil's polylingual personality based on the analysis of discursive activities.

Human speech is reflected in the composition of various texts (discourses). A polylingual person lives in the world of texts, his actions and formation take place in an active discursive activity.

The formation of a polylingual personality of pupil is a complex and complex problem. The problems of mastering the native language, the formation of bilingualism and multilingualism are directly related to the problems of interference and transposition. Structural-typological, psycholinguistic correspondenceincompatibility of related languages (Kazakh, Russian and English) determines the nature and number of possible phenomena of interference in the case of specific types of bilingualism.

Summarizing the above, the main requirements for a polylingual personality of pupil are as follows:

- The pupil's polylingual personality is a full-fledged form of personality, which includes mental, social, ethical and other components, but broken by his language, his discourse;

- The formation of a polylingual personality through school subjects is carried out in the general context of a single language education, which assumes the existence of a whole system of language learning, a common conceptual terminological apparatus in different languages;

- The purpose of language teaching in high school is inextricably linked with the formation and use of spiritual skills of schoolchildren and is considered as one of the optimal tools to achieve this goal;

- A necessary condition for the formation of a polylingual personality of pupil is the formation of the moral and spiritual world of the student, the development of his spiritual environment;

- As a polylingual pupil, a school pupil can be only as a result of language activities, which form consciousness and self-awareness.

Analyzing all the definitions, the work of scientists stated above, a polylingual personality of a pupil is a process and result of cognitive activity aimed at mastering language and speech, at self-development and becoming a student as a person.

In order to identify pupils who are fluent in several languages in General education schools, we conducted a survey among pupils of the 9th grade of the gymnasium No. 102 in Karaganda. The survey revealed the level of pupils ' proficiency in several languages (Kazakh, Russian, English). The results of the survey are shown in Figure 1. 


\section{Puplis' level of proficiency in several languages}

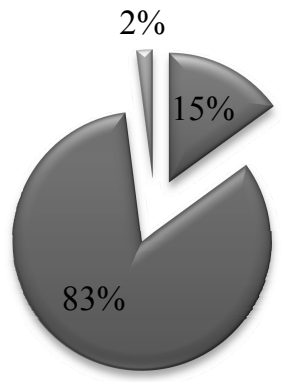

$\square$ Fluent in three languages

$\square$ Fluent in two languages

$\triangle$ Speaks only one language fluently

Figure 1. Results of the survey among school pupils

During the survey, 2 classes of the Kazakh Department were covered, the total number of respondents was 46 students. According to the results of the survey, most students do not have enough knowledge of several languages at the same time. Only 7 students are proficient in three languages, meaning that only $15 \%$ are proficient in several languages. It was found that 38 students are fluent in two languages-Kazakh and Russian, which is $83 \%$. And the number of people who speak only one language (Kazakh) was $2 \%$.

Based on the results of the survey, it can be concluded that not all pupils speak several languages. Thus, language training at school requires serious changes aimed at improving its effectiveness. We consider multilingual learning as a factor in the formation of a personality that can be involved in the complex and changing process of world reconstruction. Based on the results obtained, we consider it necessary to show in practice the advantages of teaching several languages, aimed at forming an active learning position of students through the development of special methods for the formation of a polylingual personality of a pupil in a secondary school and the creation of pedagogical conditions for mastering several languages.

The following types of activities, forms and new educational technologies contribute to the formation of a formation of a pupil's polylingual personality: dialogue lectures using various languages, information and communication projects, game and role-playing games (excursions, trips, interviews), sign and context technologies (using elements of cultural drama, semiotic text analysis, analysis of everyday objects, art), workshops of value orientations, distance educational technologies, use of interactive communication (ICQ, Skype, social pages), etc.

One of such approaches is Content and Language Integrated Learning (CLIL), which makes it possible, for example, to combine learning English or German and a special subject, i.e. to expand the general educational space through a functional approach to teaching a second language [10]. According to Liubiniene CLIL helps to integrate pupils' language abilities. For this, our teaching experience and our knowledge share the fact that these pupils are interested in all information related to their specialization. This means that they may develop their skills in CLIL classes and can be observed in their attitude in the class. As a consequence, it proofs the value of developing certain skills using CLIL for the reason to improve their study skills, which leads for a better proficiency [11].

As noted by L.G. Denisova, S.M. Mezenin, F.M. Rabinovich, T.E. Sakharova and others, one of the ways to achieve the effectiveness of the pedagogical process is intensive forms of education, which are currently internationally recognized and in demand by modern society. It should be noted that under intensive training, we consider increasing the effectiveness of the educational process by increasing motivation, using active forms and methods of learning on a communicative-activity basis, i.e., activating the learning process. In the future, we will actively work on the formation of a multi-lingual personality of a pupil who can speak several languages fluently. We plan to develop methods for learning several languages of school pupils, as well as organize language clubs.

Today, in a world with a predominance of interconnectedness and interdependence, one of the ways to prepare the younger generation for competition is polylingualism. Currently, polylingual education is the most important need for teaching academic subjects at school in two or more languages, allowing young generations to move freely in the educational space, navigate the world's secrets of science and show their abilities.

Kazakh is the state language, and Russian and knowledge of one of the foreign languages expand the horizons of the individual, contribute to his development as a versatile person, contribute to the formation of a culture of interethnic relations, tolerance and planetary thinking. A polylingual person has the opportunity 
to freely maintain himself in any foreign environment and adapt to new professional information flows or the general information planet.

Thus, the formation of a polylingual personality of a school pupil with a developed communicative and informational competence, a polylingual personality with a developed polylingual, spiritual and moral culture of interethnic relations, honoring national values, showing a steady interest in language acquisition, and a developed patriotic and civic identity is currently one of the main directions of the pedagogical process in the education system.

\title{
References
}

1 Послание Президента РК Н.А. Назарбаева народу Казахстана «Социально-экономическая модернизация - главный вектор развития Казахстана» // Казахстанская правда. - 2012. — 27 янв.

2 Коменский Я.А. Педагогическое наследие / Я.А. Коменский; сост. А.Н. Джуринсий, В.М. Кларин. - М.: Педагогика, 1987. - $412 \mathrm{c}$.

3 The education in multilanguage world. UNESCO assigned document. — Moscow, 2000.

4 Фомин М.М. Обучение иностранному языку в условиях многоязычия (двуязычия) / М.М. Фомин. — М., 1998. $213 \mathrm{c}$.

5 Наурызбай Ж.Ж. Этнокультурное образование / Ж.Ж. Наурызбай. - Алматы: Ғылым, 1997.

6 Тажибаев Т. Общая психология / Т. Тажибаев. - Алматы: Санат, 1993. - 125 с.

7 Караулов Ю.Н. Русский язык и языковая личность / Ю.Н. Караулов. — М.: Наука, 1987. — 261 с.

8 Караулов Ю.Н. Лингвистическое конструирование и тезаурус литературного языка / Ю.Н. Караулов. — М.: Наука, 1981. - $366 \mathrm{c}$

9 Богин Г.И. Модель языковой личности в её отношении к разновидностям текстов: АДД / Г.И. Богин. - Л., 1984.

10 Lasagabaster D. Foreign Language Competence in Content and Language Integrated Courses / D. Lasagabaster // The Open Applied Linguistics Journal. - Istanbul, 2008. - P. 31-42.

11 Liubiniene, V. Developing Listening Skills in CLIL Studies about Languages / V. Liubiniene. — 2009. — P. 89-93.

\author{
Р.Б. Маженова, Г.Б. Бейсенбекова, М.К. Ельшина, Я. Данек \\ Жалпы білім беретін мектепте окушылардың полилингвалды \\ тұлғасын қалыптастыру
}

\begin{abstract}
Мақала Қазақстан Республикасындағы полилингвалды білім берудің және жалпы білім беретін мектепте оқушылардың полилингвалды тұлғасын қалыптастырудың өзектілігін қарастыруға арналған. Полилингвизм және полилингвалды білім беру түсініктерін анықтаудың маңызды өзектілігі ұсынылған. Авторлар «тілдік тұлға», «полилингвалды тұлға» және «полилингвалды оқушы тұлға» түсінігіне берілген әртүрлі анықтамалар мен көзқарастарға талдау жасаған. Окушының тілдік білімі лингвометрикалық санат ретінде коммуникация мақсатында тіл теориясының негіздерін меңгеруге, сөйлеу, ақыл-ой және эстетикалық дамытуға, осы тілді тасымалдаушы халықтың мәдениетін меңгеруге бағытталған танымдық іс-әрекеттің үдерісі мен нәтижесі болып табылады. Мақалада қазіргі заман дәуіріндегі тілдерді зерттеудің негізгі аспектілері берілген. Авторлар ғалым-лингвист Г.И. Богиннің жұмысы негізінде бойынша полилингвалды тұлғаны қалыптастыру деңгейлерін қарастырған. Авторлармен полилингвалық оқушы тұлғасын қалыптастыруда оған қойылатын негізгі талаптар талданып, жүйеленген. Оған қоса, жалпы білім беретін мектептегі оқушылардың бірнеше тілді меңгеру дәрежесі анықталған. Полилингвалды оқушы тұлғасын қалыптастыруға бағытталған педагогикалық үдерістің нәтижелілігіне қол жеткізу үшін оқытудың белсенді әдістерін қолдану, арнайы әдістемелерді әзірлеу және педагогикалық жағдай тудыру қажеттілігі көрсетілген.
\end{abstract}

Кілт сөздер: тілдік тұлға, полилингвалды тұлға, оқушының полилингвалды тұлғасы, полилингвалды білім, полилингвалды индивид, полилингвизм, көптілділік.

\author{
Р.Б. Маженова, Г.Б. Бейсенбекова, М.К. Ельшина, Я. Данек
}

\section{Формирование полилингвальной личности учащихся общеобразовательной школы}

Статья посвящена рассмотрению вопросов об актуальности полилингвального образования в Республике Казахстан и формированию полилингвальной личности учащихся общеобразовательных школ. В 
ней предложена важность определения понятий полилингвизма и полилингвального образования. Авторами проанализированы различные подходы к определению понятий «языковая личность», «полилингвальная личность» и «полилингвальная личность ученика». Языковое образование школьника как категория лингвометодическая представляет собой процесс и результат познавательной деятельности, направленные на усвоение основ теории языка в целях коммуникации, на речевое, умственное и эстетическое развитие, овладение культурой народа-носителя данного языка. В статье даны основные аспекты изучения языков в современном мире. Авторами изучены уровни формирования полилингвальной личности на основе работ ученого-лингвиста Г.И. Богина. Систематизированы основные требования к формированию полилингвальной личности ученика. Кроме того, определена степень владения несколькими языками учащимися общеобразовательной школы. Для достижения результативности педагогического процесса, направленного на формирование полилингвальной личности учащегося, была показана необходимость применения активных методов обучения, разработки специальных методик и создания педагогических условий.

Ключевые слова: языковая личность, полилингвальная личность, полилингвальная личность ученика, полилингвальное образование, полилингвальный индивид, полилингвизм, многоязычие.

\section{References}

1 Poslanie Prezidenta RK N.A. Nazarbaeva narodu Kazakhstana «Sotsialno-ekonomicheskaia modernizatsiia — hlavnyi vektor razvitiia Kazakhstana» [Message of the President of Kazakhstan N.A. Nazarbayev to the people of Kazakhstan «Socio-economic modernization - the main vector of development of Kazakhstan»]. (2012, 27 January). Kazakhstanskaia Pravda - Kazakh truth [in Russian].

2 Komenskii, Ya.A. (1987). Pedahohicheskoe nasledie [Pedagogical heritage]. Dzhurinsii, A.N., Klarin, V.M. (Comps.). Moscow: Pedahohika [in Russian].

3 The education in multilanguage world (2000). UNESCO assigned document. Moscow.

4 Fomin, M.M. (1998). Obuchenie inostrannomu yazyku v usloviiakh mnohoiazychiia (dvuiazychiia) [Teaching a foreign language in the conditions of multilingualism (bilingualism)]. Moscow [in Russian].

5 Nauryzbai, Zh.Zh. (1997). Etnokulturnoe obrazovanie [Ethnocultural education]. Almaty: Hylym [in Russian].

6 Tazhibaev, T. (1993). Obshchaia psikholohiia [General psychology]. Almaty: Sanat [in Russian].

7 Karaulov, Yu.N. (1987). Russkii yazyk i yazykovaia lichnost [Russian language and language personality]. Moscow: Nauka [in Russian].

8 Karaulov, Yu.N. (1981). Linhvisticheskoe konstruirovanie i tezaurus literaturnoho yazyka [Linguistic construction and thesaurus of a literary language]. Moscow: Nauka [in Russian].

9 Bohin, G.I. (1981). Model yazykovoi lichnosti v ee otnoshenii k raznovidnostiam tekstov [The model of a linguistic personality in its relation to the varieties of texts]. Leningrad [in Russian].

10 Lasagabaster, D. (2008). Foreign Language Competence in Content and Language Integrated Courses. The Open Applied Linguistics Journal.

11 Liubiniene, V. (2009). Developing Listening Skills in CLIL. Studies about Languages. 